\title{
A study on perception about parenting among rural children
}

\section{S.C. HUNSHAL, S.S. PATIL AND P.G. HOLEYANNAVAR}

Received: 09.12.2014; Revised: 04.03.2015; Accepted: 15.03.2015

See end of the paper for authors' affiliations

\section{S.C. HUNSHAL}

AICRP on Child Development,

Department of Human

Development and Family Studies,

Rural Home Science College,

University of Agricultural

Sciences, DHARWAD

(KARNATAKA) INDIA

Email : hunshal2@gmail.com
ABSTRACT : The present study was carried out with the objectives to study the children's perception about their parents' parenting and factors influencing their perception in the year 2012-13. The sample comprised 206 High School children in the age group of 12-15 years, studying in $7^{\text {th }}$ and $8^{\text {th }}$ standards in government High Schools from 3 villages of Dharwad taluk. Children's perception about parenting was assessed using Bharadwaj et al. (1998) scale. The results revealed that majority of the children had positive perception towards their parents' parenting. This indicated that parents tend to be accepting, protecting, indulgent, realistic, moralistic and disciplining their children. Further, socio-demographic factors such as age, ordinal position, family size, educational level of the father and socio-economic status of the family had significant influence on children's perception about parenting.

KEY WORDS: Parenting, Children's perception, Parental attitude, Parenting style

- HOW TO CITE THIS PAPER : Hunshal, S.C., Patil, S.S. and Holeyannavar, P.G. (2015). A study on perception about parenting among rural children. Asian J. Home Sci., 10 (1) : 18-25. 